\title{
Keefektifan Model Pembelajaran Student Teams Achievement Division Berbantu Media Puzzle terhadap Keterampilan Berbicara Siswa
}

\author{
*Irfan Abdillah Ihsan' ${ }^{1}$, Muhajir $^{2}$, Henry Januar Saputra ${ }^{3}$
}

1,2,3 Pendidikan Guru Sekolah Dasar, Fakultas Ilmu Pendidikan, Universitas PGRI Semarang Indonesia

\author{
A R T I C L E I N F 0 \\ Article history: \\ Received 15 August 2019 \\ Received in revised form \\ 20 September 2019 \\ Accepted 10 October 2019 \\ Available online 27 \\ November 2019 \\ Kata Kunci: \\ model STAD, media puzzle \\ Keywords: \\ STAD model, puzzle media
}

\begin{abstract}
A B S T R A K
Latar belakang dalam penelitian ini adalah masih rendahnya nilai mata pelajaran Bahasa Indonesia terutama pada kemampuan berbicara siswa kelas V SD serta kurangnya penggunaan model pembelajaran yang menarik sehingga antusias siswa dalam mengikuti pembelajaran kurang dan siswa cenderung bersikap pasif Tujuan dalam penelitian ini adalah untuk mengetahui efektifitas model pembelajaran STAD berbantu media puzzle terhadap keterampilan berbicara siswa kelas $\mathrm{V}$ SD. Jenis penelitian ini adalah penelitian kuantitatif dengan menggunakan Pretest-Posttest one-Group Design. Hasil analisis data hasil belajar Pretest dan posttest dengan uji-t bahwa diperoleh dengan nilai rata-rata pretest 52 dan rata-rata nilai posttest sebesar 80,75. Dengan $\mathrm{N}=20$, Diperoleh thitung $=9,765272$ dengan taraf signifikan
\end{abstract} $5 \%$ sebesar 1,729. Karena thitung $=9,765272>$ ttabel $=1,729$, Maka hal ini menunjukkan bahwa uji mempunyai efek yang signifikan. Hal ini menunjukkan bahwa terdapat efek dari pembelajaran Model Student Teams Achievement Division (STAD) berbantu media puzzle. Saran yang dapat peneliti sampaikan adalah guru harus lebih kreatif dan inovatif dalam melakukan pembelajaran dikelas agar dapat meningkatkan keaktifan serta minat belajar peserta didik dalam mengikuti pembelajaran.

\begin{abstract}
A B S T R A C T
The background in this study is the still low value of Indonesian Language subjects in the speaking ability of fifth grade students of SDN Mangunharjo Semarang also uses an interesting learning model that encourages students to take less learning and students who are able to support it appropriately. The purpose of this study was to learn the STAD effective learning model assisted with puzzle media on the speaking skills of the fifth grade students of SDN Mangunharjo Semarang. This type of research is quantitative research using Pretest-Posttest one-Group Design. The results of data analysis of pretest and posttest learning outcomes with the t-test obtained with an average value of 52 pretests and an average posttest value of 80.75 . With $N=20$, obtained tcount $=9.765272$ with a $5 \%$ significance level of 1.729. Because tcount $=9.765272>$ ttable $=1.729$, this shows that the test has a significant effect. The Student Team Learning Model (STAD) is assisted by puzzle media. Suggestions that researchers can convey is that teachers must be more creative and innovative in learning in class so as to increase the activeness and learning interest of students in taking learning.
\end{abstract}

\section{Pendahuluan}

Keberhasilan Pendidikan adalah aspek universal yang selalu harus ada dalam kehidupan manusia. Tanpa pendidikan, ia tidak akan pernah berkembang dan berbudaya disamping itu, kehidupan juga akan menjadi tidak ada kemajuan, bahkan bisa jadi akan mengalami kemunduran. Pendidikan sangatlah penting bagi kehidupan, karena dengan adanya pendidikan manusia dapat belajar memperoleh suatu pengalaman dan pengetahuan tentang peristiwa ataupun sesuatu yang terjadi di lingkungan sekitarnya.

(Hamdani, 2016) mengatakan, sejak manusia diciptakan, pendidikan menempati urutan pertama sebagai alat yang sangat penting untuk kelangsungan hidup manusia. Meskipun belum ada istilah

Copyright (C) Universitas Pendidikan Ganesha. All rights reserved. 
pendidikan formal dan informal, substansi pendidikan sudah dibutuhkan manusia setelah manusia itu lahir.

Undang-undang No. 20 Tahun 2003, tentang Sistem Pendidikan Nasional menerangkan sebagai berikut:

"Pendidikan adalah usaha sadar dan terencana untuk mewujudkan suasana belajar dan proses pembelajaran agar peserta didik secara aktif mengembangkan potensi dirinya untuk memiliki kekuatan spiritual keagamaan, pengendalian diri, kepribadian, kecerdasan, akhlak mulia, serta keterampilan yang diperlukan dirinya, masyarakat, bangsa dan negara."

Pendidikan sangatlah penting bagi peserta didik karena dengan pendidikan peserta didik mampu menguasai pengetahuan dan keterampilan yang kelak akan digunakan hidup di masyarakat. (Hamdani, 2016)Pada masa Yunani, pendidikan dikonsepsikan sebagai proses penyiapan kehidupan manusia yang memiliki tiga tipe sebagai masyarakat yang mewujudkan Negara yang ideal, yaitu (1) Manusia sebagai pemikir dan pengatur suatu Negara; (2) Manusia sebagai kesatria dan pengaman Negara; (3) Manusia sebagai pengusaha dan penjamin kemakmuran serta kesejahteraan Negara dengan segenap warganya. Oleh karena itu melalui pendidikan peserta didik sebagai kader manusia yang memimpin Negara dimasa depan di harapkan mampu membawa pengetahuan dan keterampilanya untuk membangun bangsa. Sehingga dapat mewujudkan tujuan nasional bangsa yaitu Negara Indonesia yang merdeka, bersatu, berdaulat, adil dan makmur. Beberapa ahli pendidikan mendefinisikan konsep pendidikan sebagai berikut. Menurut Thompson dalam (Sudharto, 2009) menyatakan pendidikan adalah pengaruh lingkungan atas individu untuk menghasilkan perubahan-perubahan yang tetetap (permanen) di dalam kebiasaan-kebiasaan, tingkah-lakunya, pemikirannya, dan sikap nya. Berdasarkan pendapat tersebut dapat disimpulkan bahwa pendidikan merupakan bagian terpenting dalam kehidupan manusia. Pendidikan itu sebagai proses mendididik dan dididik, di lingkup sekolahan orang yang mendidik adalah guru dan orang yang dididik adalah siswa, dalam proses pelaksanaan pembelajaran guru sangat berperaan penting dan menjadi faktor penentu keberhasilan proses belajar dalam mencapai hasil belajar siswa yang berhasil. (Trihantoyo, 2016) Pada hakikatnya kegiatan belajar mengajar adalah proses komunikasi dan kerjasama. Dalam kehidupan sehari-hari komunikasi dan kerjasama sudah merupakan suatu kegiatan manusia yang seolah-olah sudah berjalan dengan sendirinya.

(Laa et al., 2017) Metode kooperatif merupakan metode pembelajaran yang dapat meningkatkan kinerja siswa dalam tugastugas akademik, dan membantu siswa dalam mencapai tujuan pembelajaran. Model STAD menekankan pada aktivitas dan interaksi antara siswa untuk saling memotivasi, saling membantu, bekerjasama dalam menguasai materi pelajaran, guna mencapai tujuan yang diharapkan (Sutinah, 2016), siswa di tempatkan dalam tim belajar agar bekerja sama dalam kelompok untuk menyelesaikan tugas yang diberikan oleh guru. (Nikmah et al., 2016) STAD adalah salah satu dari tipe pembelajaran kooperatif yang menekankan adanya kerjasama siswa secara berkelompok dalam memecahkan suatu masalah untuk mencapai tujuan belajar. Pembelajaran dengan model STAD mampu menciptakan pembelajaran yang aktif, inovatif, kreatif, dan menyenangkan bagi siswa selama proses pembelajaran. Pembelajaran yang demikian akan mampu membangkitkan semangat bagi siswa untuk belajar sehingga akan berpengaruh terhadap pencapaian hasil belajar siswa yang optimal. Menurut (Juraini et al., 2017) Pembelajaran kooperatif tipe STAD ini merupakan salah satu tipe dari model pembelajaran kooperatif dengan menggunakan kelompokkelompok kecil dengan jumlah anggota tiap kelompok 4-5 orang siswa secara heterogen. Diawali dengan penyampaian tujuan pembelajaran, penyampaian materi, kegiatan kelompok, kuis, dan penghargaan kelompok. Menurut Gusniar (2014) model pembelajaran kooperatif model STAD adalah salah satu model pembelajaran yang berguna untuk menumbuhkan kemampuan kerjasama, kreatif, berpikir kritis dan ada kemampuan untuk membantu teman serta merupakan pembelajaran kooperatif yang sangat sederhana. (Slavin, 2010), dalam strategi pembelajaran tipe STAD, siswa dikelompokan dalam tim-tim pembelajaran dengan anggota yang beragam dari kemampuan, jenis kelamin, ras dan etnis. (Primartadi, 2013) dalam menempatkan siswa dalam tim, jangan mengizinkan siswa memilih timnya mereka sendiri. Guru memperesentasikan pelajaran dan kemudian siswa bekerjasama tim untuk memastikan seluruh anggota tim telah menuntaskan pelajaran dengan baik. Pada akhirnya seluruh siswa memperoleh kuis individual tentang bahan ajar dan pada saat itu masing-masing individu tidak boleh saling membantu. Adapun penghargaan yang diberikan adalah penghargaan tim.

(Tarigan, 2008) Keterampilan berbahasa, terdiri atas empat aspek yaitu keterampilan menyimak atau mendengarkan (listening Skills), keterampilan berbicara (speaking Skills), keterampilan membaca (reading Skills), dan keterampilan menulis (reading Skills). Setiap keterampilan sangat berkaitan antara satu dengan yang lain. Usaha memperoleh keterampilan bahasa yang baik dan benar seseorang mulai dari 
mendengarkan. Selanjutnya berbicara dan berlatih membaca setelah melalui berbagai usaha tersebut, ia akan berusaha menulis.

(Tarigan, 2008) mengemukakan keterampilan berbicara adalah kemampuan mengucap bunyibunyi artikulasi atau kata-kata untuk mengekspresi, mengatakan serta menyampaikan pikiran, gagasan, dan perasaan. Salah satu aspek berbahasa yang harus dikuasai siswa adalah berbicara, sebab keterampilan berbicara menujang keterampilan lainnya, seharusnya keterampilan berbicara diajarkan sedini mungkin, keterampilan berbicara penting dikuasai siswa agar mampu mengembangkan kemampuan berpikir, membaca, menulis, menyimak, dan penyampaian ide kepada orang lain secara lisan.

Salah satu aspek berbahasa yang harus dikuasai oleh siswa adalah berbicara, sebab keterampilan berbicara menunjang keterampilan lainnya . Pentingnya penguasaan keterampilan berbicara untuk siswa Sekolah Dasar juga dikatakan oleh Farris (Yunara, 2012) bahwa pembelajaran keterampilan berbicara penting dikuasai siswa agar mampu mengembangkan kemampuan berpikir, membaca, menulis, dan menyimak. Kemampuan berpikir mereka akan terlatih ketika mereka mengorganisasikan, mengonsepkan, mengklarifikasikan, dan menyederhanakan pikiran, perasaan, dan ide kepada orang lain secara lisan. Akan tetapi, masalah yang terjadi di lapangan adalah tidak semua peserta didik mempunyai kemampuan berbicara yang baik. Oleh sebab itu, pembinaan keterampilan berbicara harus dilakukan sedini mungkin.

Model-model pembelajaran dirancang untuk tujuan-tujuan tertentu, pengajaran konsep-konsep informasi, cara-cara untuk berpikir, studi nilai-nilai sosial dan sebagaian meminta siswa untuk terlibat aktif dalam pengerjaan tugas-tugas kognitif dan sosial tertentu (Setiasih \& Panjaitan, 2016)

Menurut pengamatan di kelas V SDN Mangunharjo Semarang, terdapat permasalahan dalam proses pembelajaran dikarenakan guru masih menggunakan pembelajaran yang berpusat pada guru, Berdasarkan informasi yang telah didapat dari Ibu Eli guru kelas V SDN Mangunharjo Semarang, guru cenderung sering menggunakan model pembelajaran ceramah. Dalam proses pembelajaran guru sangat jarang menggunakan model dan media pembelajaran, pada saat pelaksanaan pembelajaran berlangsung sehingga siswa cenderung bosan yang ditandai dengan siswa bermain sendiri dan tidak memperhatikan saat pembelajaran berlangsung sehingga pelaksanaan kegiatan belajar mengajar kurang efektif dan menyebabkan materi yang telah disampaikan oleh guru tidak di terima secara menyeluruh oleh siswa.

Berdasarkan hasil observasi pada saat proses pembelajaran dapat disimpulkan bahwa kemampuan siswa dalam keterampilan berbicara kurang. Hal itu dapat dibuktikan dengan hasil pengamatan di dalam kelas seperti pada tabel 1 berikut:

Tabel 1. Nilai Harian Berbicara

\begin{tabular}{ccccc}
\hline No. & Kriteria Ketuntasan Minimal & Jumlah & Persentase & Keterangan \\
\hline 1. & $<75$ & 17 siswa & $85 \%$ & Tidak Tuntas \\
2. & $>75$ & 3 siswa & $15 \%$ & Tuntas \\
\hline & & & & (Sumber: Data Nilai Harian)
\end{tabular}

Dari Tabel 1. dapat dilihat nilai harian kemampuan berbicara siswa Kriteria Ketuntasan Minimal (KKM) 75, sebanyak 17 siswa (85\%) tidak tuntas atau masih di bawah KKM. Sedangkan hanya 3 siswa (15\%) tuntas atau sudah mencapai KKM. Diskripsi permasalahan di atas menunjukkan bahwa ada masalah pada kemampuan berbicara perlu diperbaiki agar dapat meningkatkan kemampuan berbicara siswa pada mata semua mata pelajaran dan lebih spesifik pada Kelas V.

Berdasarkan latar belakang penelitian ini, dan bedasarkan masalah-masalah yang di paparkan di atas merupakan faktor utama yang melatar belakangi peneliti untuk mengadakan penelitian yang berjudul "Keefektifan Model Pembelajaran STAD berbantu Media Puzzle Terhadap Kemampuan Berbicara Kelas V SDN Mangunharjo Semarang".

\section{Metode}

Metode Penelitian yang dilakakukan merupakan penelitian kuantitatif. Metode yang digunakan dalam penelitian ini adalah metode eksperimen dapat diartikan sebagai metode penelitian yang di gunakan untuk mencari pengaruh perlakuan tertentu terhadap yang lain dalam kondisi yang terkendalikan (Sugiyono, 2007).

Desain yang digunakan dalam penelitian ini adalah One-Grup Pretest-posttest design. Desain ini terdapat pretest, sebelum di beri perlakuan. Dengan demikian hasil perlakuan dapat di ketahui lebih akurat, karena membandingkan dengan keadaan sebelum di beri perlakuan (Sugiyono, 2007). Design ini dapat di gambarkan sebagai berikut: 


\section{$01 \times 02$}

Keterangan:

$01=$ Nilai pretest (Sebelum di beri perlakuan model STAD berbantu media puzzle)

O2 = Nilai Posttest (Setelah di beri perlakuan model STAD berbantu media puzzle)

02-01 = Efektifitas model STAD berbantu media puzzle terhadap kemampuan berbicara siswa

Siswa kelas V akan diberi pretest untuk mengetahui kondisi awal sebelum diberi perlakuan. Setelah hasil pretest didapat, barulah siswa kelas eksperimen diberi perlakuan dengan menggunakan model pembelajaran Student Team Achievement Division (STAD) berbantu media puzzle. siswa diberi posttest untuk mendapatkan hasil akhir setelah siswa diberi perlakuan.penelitian.

\section{Hasil dan Pembahasan}

\section{A. Nilai Awal}

Deskripsi nilai awal keterampilan berbicara kelas V SD N Mangunharjo Semarang. Jumlah skor dengan responden 20 orang adalah 1040, rata-rata skor adalah 52,00. Selanjutnya data dikelompokkan dalam Tujuh kategori, yaitu kategori jelek, sangat kurang, kurang, kurang baik, cukup, baik, dan sangat baik.

Tabel 2. Nilai Awal Keterampilan Berbicara

\begin{tabular}{cccl}
\hline Interval & Frekuensi & Persentase & \multicolumn{1}{c}{ Kategori } \\
\hline $0-14$ & 0 & 0 & Jelek \\
$15-29$ & 2 & 10 & Sangat Kurang \\
$30-44$ & 4 & 20 & Kurang \\
$45-59$ & 5 & 25 & Kurang Baik \\
$60-74$ & 7 & 35 & Cukup \\
$75-84$ & 1 & 5 & Baik \\
$85-100$ & 1 & 5 & Sangat Baik \\
\hline Jumlah & $\mathbf{2 0}$ & $\mathbf{1 0 0 \%}$ & \\
\hline
\end{tabular}

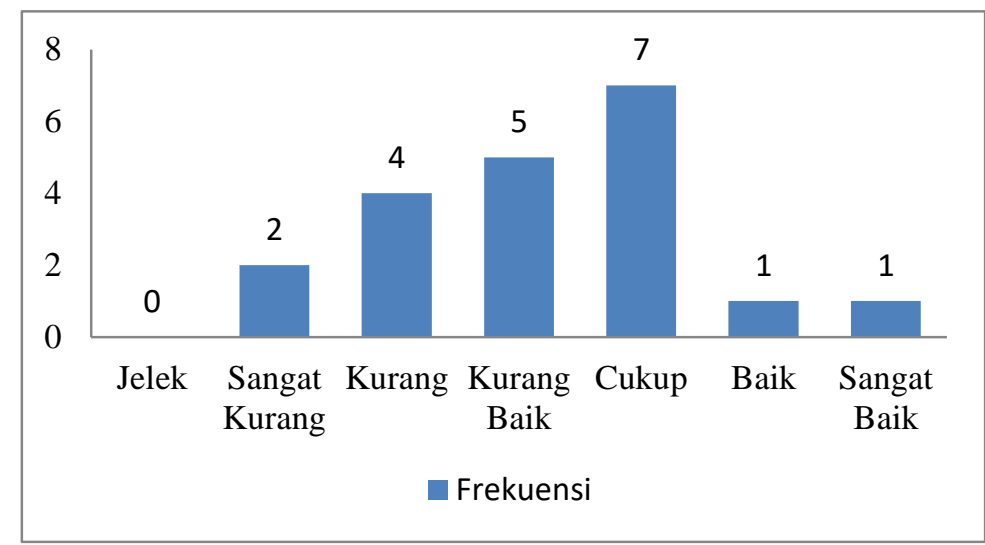

Gambar 1.

Diagram Nilai Awal Kemampuan Berbicara

\section{B. Nilai Akhir}

Deskripsi nilai akhir keterampilan berbicara kelas V SD N Mangunharjo Semarang. jumlah skor dengan responden 20 orang adalah 1615, rata-rata skor adalah 80,75. Selanjutnya data dikelompokkan dalam Tujuh kategori, yaitu kategori jelek, sangat kurang, kurang, kurang baik, cukup, baik, dan sangat baik. 
Tabel 3. Nilai Akhir Keterampilan Berbicara

\begin{tabular}{cccl}
\hline Interval & Frekuensi & Persentase & \multicolumn{1}{c}{ Kategori } \\
\hline $0-14$ & 0 & 00 & Jelek \\
$15-29$ & 0 & 0 & Sangat Kurang \\
$30-44$ & 0 & 0 & Kurang \\
$45-59$ & 0 & 0 & Kurang Baik \\
$60-74$ & 2 & 10 & Cukup \\
$75-84$ & 9 & 45 & Baik \\
$85-100$ & 9 & 45 & Sangat Baik \\
\hline Jumlah & $\mathbf{2 0}$ & $\mathbf{1 0 0 \%}$ & \\
\hline
\end{tabular}

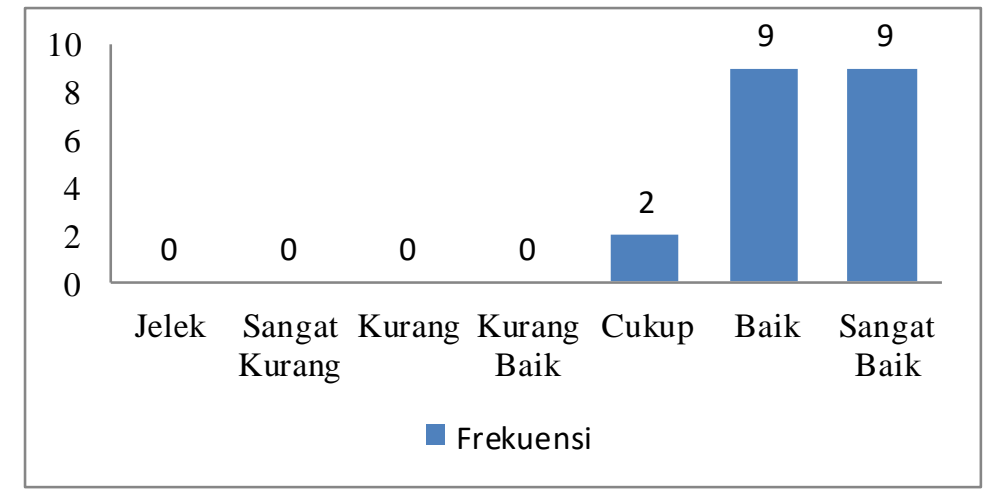

\section{Gambar 2.}

Diagram Nilai Akhir Kemampuan Berbicara

Berdasarkan Tabel 3 dan Gambar 2, dapat disimpulkan bahwa nilai akhir keterampilan berbicara siswa kelas V SD N Mangunharjo adalah 10\% cukup, 45\% baik, dan $45 \%$ sangat baik.

\section{Perbandingan Nilai Awal dan Akhir Keterampilan berbicara}

Tabel 4. Nilai Kemampuan Berbicara

\begin{tabular}{lccccc}
\hline \multicolumn{1}{c}{ Ienis Tes } & Nilai Terendah & Nilai Tertinggi & Rata-rata & Tuntas & Tidak Tuntas \\
\hline Pretest & 25 & 85 & 52 & $2(10 \%)$ & $18(90 \%)$ \\
Posttest & 65 & 95 & 80,75 & $18(90 \%)$ & $2(10 \%)$ \\
\hline
\end{tabular}

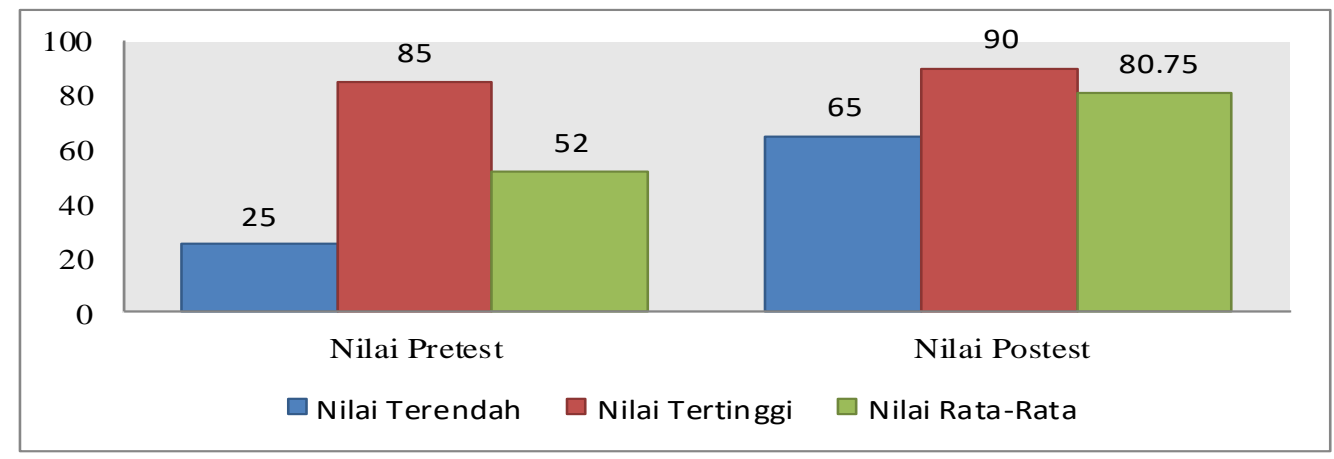

Gambar 3.

Diagram Nilai Kemampuan Berbicara

Berdasarkan Tabel 4. dan Gambar 3. hasil penelitian tersebut maka diperoleh nilai terendah pada uji pretest sebesar 25, dan nilai tertinggi sebesar 85 dan nilai rata-rata sebesar 52 . Ketuntasan hasil belajar pada uji pretest siswa yang tuntas mencapai KKM 75 sebanyak 2 siswa dan siswa yang tidak tuntas 
sebanyak 18 siswa. Sedangkan pada hasil posttest diperoleh nilai terendah sebesar 65, nilai tertinggi 90 dan nilai rata-rata sebesar 80,75 . Ketuntasan hasil belajar pada uji posttest siswa yang tuntas memcapai KKM 75 sebanyak 18 dan siswa yang tidak tuntas sebanyak 2 siswa. Dengan melihat data hasil penelitian tersebut menunjukkan bahwa telah terjadi peningkatan hasil penelitian belajar yang signifikan setelah diberi model pembelajaran Student Teams Achivement Division (STAD) berbantu media puzzle.

\section{Uji Persyaratan Analisis Data}

Uji normalitas digunakan untuk mengetahui apakah sampel dari populasi berdistribusi normal atau tidak, untuk menguji normalitas ini digunakan uji lilliefors. Misalkan sampel acak dengan menggunakan $\mathrm{X}_{1} \mathrm{X}_{2}, \mathrm{X}_{n}$. Berdasarkan sampel ini akan diuji hipotesis nol dan hipotesis alternatifnya, yaitu:

Ho : Sampel tidak berasal dari populasi yang berdistribusi normal. Ha : Sampel berasal dari populasi yang berdistribusi normal.

Adapun langkah-langkah untuk menguji kenormalan suatu sampel yaitu kriteria pengujian hipotesis pada uji lilliefors yaitu apabila diperoleh nilai $\mathrm{L}_{0} \mathrm{~L}_{\text {tabel }}$ maka $\mathrm{H}_{0}$ diterima atau sampel berasal dari populasi yang berdistribusi normal. Hasil uji normalitas diperoleh nilai pada tabel 5 berikut:

Tabel 5. Hasil Uji Normalitas

\begin{tabular}{cccc}
\hline Hasil Belajar & $\mathrm{L}_{\text {tabel }}$ & $\mathrm{L}_{\text {hitung }}$ & Keterangan \\
\hline Pretest & 0,190 & 0,1425 & Normal \\
Posttest & 0,190 & 0,1602 & Normal \\
\hline
\end{tabular}

Berdasarkan Tabel 5. dengan $\mathrm{n}=20$ dengan taraf signifikan sebesar $5 \%$ maka diperoleh nilai Ltabel $=0,190$. Hasil uji normalitas awal dengan menggunakan hasil belajar pretest pada tabel 4.2 menunjukkan nilai Lhitung $=0,1425$. Sedangkan pada hasil uji normalitas akhir diperoleh nilai Lhitung= 0,1602 . Dengan demikian hasil uji normalitas dengan menggunakan uji lilliefors diperoleh nilai $0,1425 \leq$ 0,190 dan 0,1602 $\leq$ 0,190 maka Lhitung $\leq$ Ltabel, maka dapat disimpulkan bahwa sampel berasal dari populasi yang berdistribusi normal.

\section{E. Uji Hipotesis}

Uji hipotesis pada penelitian ini, peneliti menggunakan uji t-test yang dilakukan untuk membandingkan hasil data dari perhitungan pretest dan pottest serta menentukan ada atau tidaknya perbedaan sebagai akibat dari perlakuan X yaitu pembelajaran mengunakan model pembelajaran Student Teams Achievement Division (STAD) berbantu media puzzle terhadap keterampilan berbicara dianalisis dengan uji t-test. Hipotesis yang diajukan dalam penelitian ini adalah terdapat efektifitas model pembelajaran Student Teams Achievement Division (STAD) berbantu media puzzle terhadap keterampilan berbicara SDN Mangunharjo Semarang.

$\mathrm{H}_{\mathrm{o}}$ : $\quad$ Tidak ada efek model pembelajaran Student Teams Achievement Division (STAD) berbantu media puzzle terhadap keterampilan berbicara siswa kelas V SDN Mangunharjo.

$\mathrm{H}_{\mathrm{a}}$ : Model pembelajaran Student Teams Achievement Division (STAD) berbantu media puzzle efektif meningkatkan keterampilan berbicara siswa kelas V SDN Mangunharjo.

Setelah dilakukan analisis maka disajikan pada tabel 6 berikut:

Tabel 6. Hasil Perhitungan Uji-t

\begin{tabular}{cccccccc}
\hline Subyek & Hasil Belajar & Rata-rata & $\mathbf{N}$ & $\mathbf{M}_{\mathbf{d}}$ & $\sum \mathbf{x}^{2} \mathbf{d}$ & $\mathbf{t}_{\text {hitung }}$ & $\mathbf{t}_{\text {tabel }}$ \\
\hline Kelas V SDN & Pretest & 52 & 20 & 28,75 & 3293,75 & 9,765272 & 1,729 \\
Mangunharjo & Posttest & 80,75 & 20 & 28,75 & 3293,75 & 9,765272 & 1,729 \\
\hline
\end{tabular}

Berdasarkan Tabel 6. analisis data nilai Pretest dan posttest dengan uji-t bahwa diperoleh dengan nilai rata-rata pretest 52 dan rata-rata nilai posttest sebesar 80,75. Dengan $N=20$, Diperoleh thitung $=$ 9,765272 dengan taraf signifikan $5 \%$ sebesar 1,729. Karena thitung $=9,765272>$ ttabel $=1,729$, Maka hal 
ini menunjukkan bahwa uji t mempunyai efek yang signifikan. Hal ini menunjukkan bahwa terdapat efek dari pembelajaran Model Student Teams Achievement Division (STAD) berbantu media puzzle

Penelitian ini termasuk penelitian kuantitatif. Desain yang digunakan adalah One Group Pretest Posttest Design. Sebelum penelitian di laksanakan peneliti mempersiapkan RPP yang di laksanakan. Penelitian ini menggunakan Model Student Teams Achievement Division (STAD) berbantu media puzzle, model ini penjelasan sederhananya yaitu membagi kelompok kecil yang beranggotakan 4-5 siswa. Sebelum pelaksanaan posttest terlebih dahulu di laksanakan pretest dimana pada proses pretest ini bertujuan untuk pengambilan nilai keterampilan berbicara sebelum diberikan Model Student Teams Achievement Division (STAD) berbantu media puzzle dengan membuat kesimpulan bacaan teks yang telah diberikan lalu menyampaikan nya di depan kelas. Setelah pretest di laksanakanlah posttest dimana pelaksanaan posttest. Posttest dilaksanakan untuk mengetahui hasil nilai akhir setelah di beri perlakuan. Setelah melakukan penelitian dengan menggunakan penerapan model Student Teams Achievement Division (STAD) berbantu Media Puzzle menimbulkan reaksi: 1) Konflik interpersonal. Terdapat permasalahan yang dialami siswa yaitu siswa dituntut untuk berpikir bagaimana cara menguasai cerita. Kemudian siswa mampu menemukan teknik belajar penguasaan cerita yang ditelah dibuat, 2) Relasi antar kelompok. Saling membantu anggota kelompok untuk belajar memahami gambar yang ada dalam media puzzle, 3) Siswa lebih antusias belajar ketika menggunakan Model Pembelajaran yang berbeda dari biasanya dan ketika penggunaan media puzzle siswa sangat tertarik.

Untuk mengetahui ada atau tidak efek keterampilan berbicara dengan menggunakan model Student Teams Achievement Division (STAD) berbantu puzzle pada siswa kelas V SD N Mangunharjo Semarang diperlukan suatu langkah yaitu uji hipotesis. Analisis data nilai Pretest dan posttest dengan uji-t bahwa diperoleh dengan nilai rata-rata pretest 52 dan rata-rata nilai posttest sebesar 80,75 . Dengan $N=20$, Diperoleh thitung $=9,765272$ dengan taraf signifikan $5 \%$ sebesar 1,729. Karena thitung $=9,765272>$ ttabel $=1,729$, Maka hal ini menunjukkan bahwa uji t mempunyai efek yang signifikan. Hal ini menunjukkan bahwa terdapat efek dari pembelajaran Model Student Teams Achievement Division (STAD) berbantu media puzzle.

\section{Simpulan dan Saran}

Berdasarkan hasil penelitian yang dilakukan peneliti pada siswa kelas V SD N Mangunharjo Semarang, maka dapat disimpulkan bahwa Model Student Teams Achievement Division (STAD) efektif terhadap keterampilan berbicara siswa kelas V SD N Mangunharjo Semarang. Hal ini diperkuat dengan rata-rata nilai posttest adalah 80,75 dan nilai rata-rata pretes adalah 52. Berdasarkan uji statistik dapat diketahui dari perhitungan uji-t dalam hipotesis, yaitu bahwa thitung lebih besar sama dengan dari ttabel dengan perhitungan 9,765272 $\geq 1,729$ pada taraf signifikan $5 \%$.

Berdasarkan kesimpulan di atas maka saran yang dapat diberikan untuk memajukan dan memperbaiki pembelajaran pada kelas IV SD N Mangunharjo Semarang sebagai berikut: 1)Bagi Sekolah, Sekolah sebaiknya memberikan fasilitas yang memadai untuk pelaksanaan pembelajaran misalnya: properti pendukung seperti media pembelajaran. 2) Bagi Guru, Guru hendaknya memberikan sebuah pembelajaran yang inovatif yang salah satunya dapat menggunakan model pembelajaran Student Teams Achievement Devision untuk meningkatkan kemampuan berbicara siswa, Guru harus mampu menciptakan suasana yang aktif dan menyenangkan untuk mendorong motivasi belajar siswa, Guru harus mampu menguasai materi dengan baik dan membagi waktu dengan baik agar terciptanya tujuan pembelajaran yang akan dicapai, Guru hendaknya menggunakan media pembelajaran ketika melaksanakan kegiatan belajar mengajar agar siswa lebih antusias mengikuti pembelajaran. 3)Bagi Siswa, Siswa harus mampu memahami materi yang telah disediakan guru, sehingga pelaksanaan pembelajaran berjalan dengan lancar. 4) Bagi Peneliti Selanjutnya, Peneliti selanjutnya diharapkan mampu mempelajari kekurangan-kekurangan yang ada di dalam penelitian ini, sehingga peneliti selanjutnya mendapatkan solusi yang tepat dan bisa diterapkan dipenelitian yang dilakukan selanjutnya.

\section{Daftar Rujukan}

Hamdani. (2016). Dasar-Dasar Kependidikan. Pustaka Setia.

Gusniar. 2014. Penerapan Model Pembelajaran Kooperatif Tipe Student Teams Achievment Division (STAD) Dalam Meningkatkan Hasil Belajar Siswa Pada Mata Pelajaran IPS Kelas IV SDN No. 2 Ogoamas II. Jurnal Kreatif Tadulako Online, 2(1), (198-221).

Juraini, J., Taufik, M., \& Gunada, I. W. (2017). Pengaruh Model Pembelajaran Kooperatif Tipe STAD (Student Team Achievement Division) dengan Metode Eksperimen Terhadap Keterampilan Proses 
Sains dan Hasil Belajar Fisika pada Siswa SMA Negeri 1 Labuapi Tahun Pelajaran 2015/2016. Jurnal Pendidikan Fisika Dan Teknologi, 2(2), 80. https://doi.org/10.29303/jpft.v2i2.293

Laa, N., Winata, H., \& Meilani, R. I. (2017). Pengaruh Model Pembelajaran Kooperatif Tipe Student Teams Achievement Division Terhadap Minat Belajar Siswa. Jurnal Pendidikan Manajemen Perkantoran, 2(2), 139. https://doi.org/10.17509/jpm.v2i2.8115

Nikmah, E. H., Fatchan, A., \& Wirahayu, Y. A. (2016). Model Pembelajaran Student Teams Achievement Divisions (STAD), Keaktifan dan Hasil Belajar Siswa. Jurnal Pendidikan Geografi, 3(3), 1-17. http://jurnal-online.um.ac.id/data/artikel/artikelE91D7FB9C21685AA36E47BE7A44B0CC7.pdf

Primartadi, A. (2013). Pengaruh metode student teams-achievement division (STAD) dan problem based learning terhadap hasil belajar ditinjau dari potensi akademik siswa SMK otomotif. Jurnal Pendidikan Vokasi, 2(2), 143-153. https://doi.org/10.21831/jpv.v2i2.1024

Setiasih, S. Della, \& Panjaitan, R. L. (2016). Penggunaan Model Inkuiri Untuk Meningkatkan Hasil Belajar Siswa Pada Materi Sifat-Sifat Magnet Di Kelas V Sdn Sukajaya Kecamatan Jatinunggal Kabupaten Sumedang. Penggunaan Model Inkuiri Untuk Meningkatkan Hasil Belajar Siswa Pada Materi Sifat-Sifat Magnet Di Kelas V Sdn Sukajaya Kecamatan Jatinunggal Kabupaten Sumedang, 1(1), 421-430. https://doi.org/10.23819/pi.v1i1.3051

Slavin, R. E. (2010). Cooperative learning teori riset dan praktek. Nusa Media.

Sudharto, dkk. (2009). Pengantar Pendidikan. FIP IKIP PGRI Semarang.

Sugiyono. (2007). Statistika untuk Penelitian (Revisi Terbaru). Alfabeta.

Sutinah, dkk. 2016. Model Pembelajaran Kooperatif Tipe Students Team Achievment Devision (STAD). Seminar Nasional Pengembangan Profesionalisme Pendidik Untuk Membangun Karakter Anak Bangsa, Pascasarjana Universitas Negeri Malang, Vol. 2(2016).

Tarigan, G. (2008). Berbicara Sebagai Suatu Keterampilan Berbahasa. Angkasa Bandung.

Trihantoyo, S. (2016). Implementasi Tipe Student Teams - Achievement Divisions ( Stad) Sebagai Model Pembelajaran Kooperatif Untuk Meningkatkan Pemahaman Konsep Manajemen Paud. Syunu Trihantoyo Program Studi Manajemen Pendidikan, Fakultas Ilmu Pendidikan Universitas Negeri Sur. Jurnal Dinamika Manajemen Pendidikan, 1(1), 15-23.

Yunara, Y. (2012). Peningkatan Keterampilan Berbicara Menggunakan Gambar Berseri Pembelajaran Bahasa Indonesia Kelas Vmadrasah Ibtidaiyah Swasta Nahdatul Ulama 2 Pontianak. 